\title{
Mining data from 1000 genomes to identify the causal variant in regions under positive selection
}

\author{
Shari Grossman ${ }^{1,2,3^{*}+}$, llya Shlyakhter ${ }^{1,2+}$, Elinor K Karlsson ${ }^{1,2}$, Shervin Tabrizi ${ }^{1,2}, K_{\text {Kristian Andersen }}^{1,2}$, John Rinn², \\ Eric Lander ${ }^{2}$, Steve Schaffner ${ }^{2}$, Pardis C. Sabeti ${ }^{1,2}$, The 1000 Genomes Project \\ From Beyond the Genome: The true gene count, human evolution and disease genomics \\ Boston, MA, USA. 11-13 October 2010
}

The human genome contains hundreds of regions in which the patterns of genetic variation indicate recent positive natural selection, yet for most of these the underlying gene and the advantageous mutation remain unknown. We recently reported the development of a method, Composite of Multiple Signals (CMS), that combines tests for multiple signals of natural selection and increases resolution by up to 100 -fold.

Applying CMS to candidate selected regions from the International Haplotype Map, we localized several hundred signals to $\sim 50-100 \mathrm{~kb}$, identifying individual gene and polymorphism targets of selection. These regions included genes involved in processes known to be targets of selection, such as infectious disease, skin pigment, metabolism, and hair and sweat. We further identified many candidates that are similar to regulatory elements. In several regions, we identified variants that are significantly associated with the expression of nearby genes in the selected population. Moreover nearly half of the $\sim 200$ regions we examined localized to regions with no genes. Thirty of the regions contain long noncoding RNAs that have been shown to often regulate nearby genes, suggesting that variation within the RNAs might have functional consequences.

With preliminary data now available from the 1000 Genomes Project, we are beginning to explore full sequence data, which should contains most if not all of the causal selected polymorphisms. We extended the CMS method to the preliminary data set, validating our previously identified candidates and identifying many new intriguing coding and regulatory variants.

\footnotetext{
† Contributed equally

${ }^{1}$ Center for Systems Biology and Department of Organismic and Evolutionary Biology, Cambridge, MA 02138, USA

Full list of author information is available at the end of the article
}

Author details

${ }^{1}$ Center for Systems Biology and Department of Organismic and Evolutionary Biology, Cambridge, MA 02138, USA. ${ }^{2}$ Broad Institute of Harvard and MIT, Cambridge, MA 02139 USA. ${ }^{3}$ Harvard Medical School, Boston, MA 0211, USA.

Published: 11 October 2010

doi:10.1186/gb-2010-11-S1-I22

Cite this article as: Grossman et al:: Mining data from 1000 genomes to identify the causal variant in regions under positive selection. Genome Biology 2010 11(Suppl 1):I22.
Submit your next manuscript to BioMed Central and take full advantage of:

- Convenient online submission

- Thorough peer review

- No space constraints or color figure charges

- Immediate publication on acceptance

- Inclusion in PubMed, CAS, Scopus and Google Scholar

- Research which is freely available for redistribution

Submit your manuscript at www.biomedcentral.com/submit
C Biomed Central 